Egyptian Journal of Aquatic Biology \& Fisheries

Zoology Department, Faculty of Science,

Ain Shams University, Cairo, Egypt.

ISSN $1110-6131$

Vol. 25(1): $75-89$ (2021)

www.ejabf.journals.ekb.eg

\title{
Impact of bioaccumulation and biosedimentation of some heavy metals on some biochemical responses in the sole fish, Solea solea inhabiting Lake Qarun, Egypt.
}

\author{
Ahmed Y. H. Elwasify ${ }^{1}$, Mohamed H. Ghanem ${ }^{2 *}$, Mahmoud M. M. El-Bamby ${ }^{1}$ and \\ Foaad A. F. Ali ${ }^{3}$ \\ 1 Department of Environment and Bio-Agriculture, Faculty of Agriculture (Cairo), Al-Azhar University, Egypt \\ 2 Department of Zoology, Faculty of Science, (Cairo), Al-Azhar University, Egypt \\ 3 Department of Plant Protection, Faculty of Agriculture (Cairo), Al-Azhar University, Egypt
}

* Correspondence: mohamedhamed.201@azhar.edu.eg

\section{ARTICLE INFO}

Article History:

Received: Dec. 21, 2020

Accepted: Jan. 2, 2021

Online: Jan. 7, 2021

Keywords:

Heavy metals;

Bioaccumulation;

biochemical responses;

Sole fish;

Solea solea;

Lake Qarun.

\section{ABSTRACT}

The present study was conducted during the period from October 2015 to September 2016 to investigate the bioaccumulation and biosedimentation factors of five heavy metals in Solea solea inhabiting lake Qarun, Egypt. Water, sediments, and fish samples were collected during the year, 2015-2016. The present study exhibited that, the maximum values of bioaccumulation and biosedimentation factors were recorded in the liver and the minimum values were observed in the muscles. The results exhibited the differences of some heavy metals accumulation in different tissues of fish and the gradual accumulation and increase in the liver, gills and muscles during summer and spring than other seasons. The liver of $S$. solea accumulates higher levels of $\mathrm{Cu}, \mathrm{Fe}$ and $\mathrm{Zn}$ than other organs. The results showed that the bioaccumulation factor of $\mathrm{Cd}, \mathrm{Fe}$ and $\mathrm{Mn}$ in fishes were greater than biosedimentation factor and this implies that the fishes bioaccumulated these metals from the water. While copper and zinc accumulation in fishes from water were lower than that from sediment and this implies that the fishes bioaccumulated these metals from the sediment

Results recorded the higher values of total proteins in the kidney and liver of $S$. solea during winter, however, total proteins in the muscles was peaked during spring. On the other hand, total lipids in the target organs exhibited increasing levels during autumn and spring. Results supported that, the elevation of ASAT and ALAT activities in the target organs might reflect the early toxic effects of heavy metals on the hepatic enzyme activities which may lead to tissue damage and liver necrosis. Analysis of variance indicated that there are significant differences $(p>0.05)$ in one way and non-significance in two ways.

\section{INTRODUCTION}

Lake Qarun constitutes one of very important sectors in the Egyptian fisheries. Moreover, it is a closed elongated marine lake with irregular shape of about $40 \mathrm{~km}$ at length and about $6 \mathrm{~km}$ mean width (Figure 1). Lake Qarun containing different types of fish, snails and seabirds along the year. So, it is considered as one of the most important wintering and nesting sites for many species of the migratory birds. It is approximately 55000 feddans (22000 hectares) or approximately 107 square kilometers (Sabae\& Ali, 2004; Ghanem, 2011; Sabae\& Mohamed, 2015; Ragab, 2017; Bakry et al., 2018 and Mohamed, 2019). 


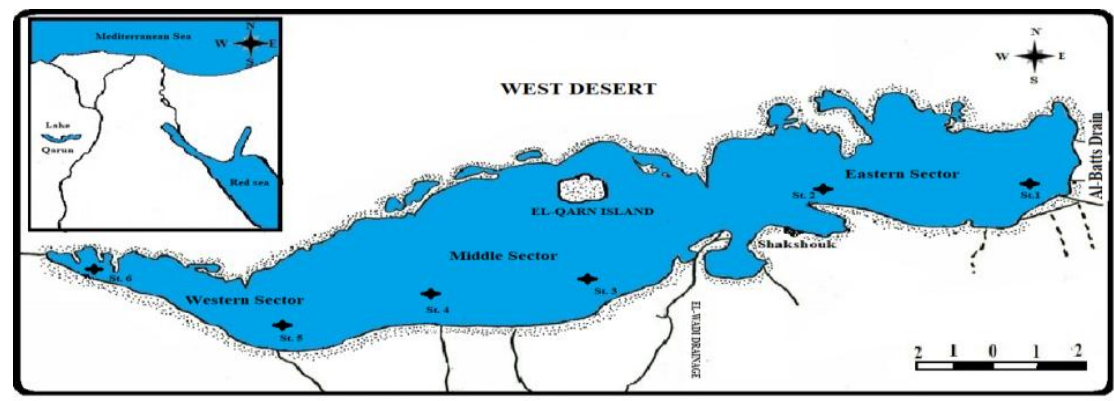

Figure 1. A map of Lake Qarun showing the study area.

Lake Qarun is a closed system acts as a reservoir for agricultural and sewage drainage water of El-Faiyoum Province. The drainage waters discharged into the lake are highly concentrated solids, nutrients, pesticides, heavy metals and organic maters (Ali \&Fishar, 2005; Mohamed \& Gad, 2008; Mohamed, 2009; Ghanem, 2011 and Mohamed, 2019). It receives annually about 450 million cubic meters of agricultural drainage water and domestic waste water. The amount of lake water decreased annually to making the balances by evaporation (El-Shabrawy\&Taha, 1999 and Sabae\&Ali, 2004). The accumulation of chemical pollutants (heavy metals, pesticides and other pollutants) is expected to increase annually in all its components (e.g. water, sediment and fish) and to change their quality and affect their aquatic life (Mansour \& Sidky, 2003). Sediment quality is a good indicator of pollution in water column, where it tends to concentrate the heavy metals and other organic pollutants (Saeed \& Shaker, 2008).

Solea solea is one of the dominant fish species recorded from the lake waters (Ghanem, 2011 and Mohamed, 2019). Fish living in polluted water tends to accumulate heavy metals in their tissues. Generally, accumulation depends on metal concentration, time of exposure, pathway of metal uptake, environmental conditions and intrinsic factors, fish age and feeding habits. Some heavy metals are essential for the growth and well-being of living organisms. However, they are likely to show toxic effects when organisms are exposed to higher levels than normally required. Other elements $(\mathrm{Cd}, \mathrm{Hg}, \mathrm{Ni}, \mathrm{Co}$ and $\mathrm{Pb})$ are not essential for metabolic activities and exhibit toxic properties (Cogun \&Kargin, 2004; Delaney \&Klesius, 2004; Benli, 2005 and Ghanem et al., 2015). Low concentrations of essential trace elements may suppress physiological action, leading to abnormal growth of organisms (Bowen, 1966 and Mansour et al., 2000). Bioaccumulation and biosedimentation factors from environment to fish tissue changes according to the species of the chemical, the metabolite properties of the tissues and the pollution degree of the environment (Ayas et al., 2007 and Ozmen et al., 2008). Biochemical composition in different fish species varies with age, sex, season and diet and the heavy metals are found to influence the biochemical composition of fingerlings (Shakoori et al., 1996).

Impact of contaminants on aquatic ecosystems can be evaluated by measuring biochemical parameters in the liver of fish that respond specifically to the degree and type of contamination (Barhoumi et al., 2012 and Chavan \& Muley, 2014). Changes in the enzymes activities and muscles composition can be used as biomarkers for tissue damage (Nelson \& Cox, 2000; Almeida et al., 2002 and Adhikari et al., 2004). 
The present study aimed to get information about the seasonal variations in bioaccumulation and biosedimentation factors of heavy metals components (water, sediments and inhabiting fishes) in lake Qarun as a bioindicator for pollution level and its effects on some biochemical aspects of S. solea.

\section{MATERIALS AND METHODS}

The present work was conducted at the laboratories of Zoology Department, Fuculty of Science, Al-Azhar University, Nasr City, Cairo, Egypt, during the period of study.

\section{Samples collection:}

Water, sediments and fish samples were collected from the the lake during the period from October, 2015 to September, 2016.

\section{Water and sediments sampling:}

Surface water samples were collected by a Ruttner bottle water sampler with capacity of one/two litters. For measurement of heavy metals samples were collected in polyethylene bottles. Moreover, sediment samples were collected from using Van Veen type, grab. Sampling was device at the same time of water collection. After collection, the sediment samples were transferred to the laboratory in plastic bags.

\section{Fish sampling:}

A total number of 80 fish (about 20 fish/season) were seasonally collected for freshly examined or preserved for later examination. In the laboratory, fishes were identified; the total and standard lengths of each fish (Figure 2) were measured and recorded to the nearest centimeter $(\mathrm{cm})$. While, the body weight was determined to the nearest gram $(\mathrm{g})$. After dissection, a known weight of the muscles was kept under freezing condition at $4{ }^{\circ} \mathrm{C}$ until the latter examinations.

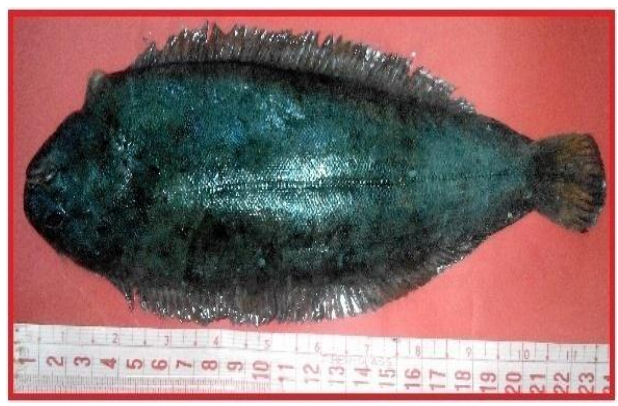

Figure 2. The sole fish, Solea solea, collected from Lake Qarun.

\section{Heavy metal analysis:}

Concentrations of heavy metals in water were determined after digestion by nitric acid according to Eaton \& Franson (2005). Concentrations of heavy metals in sediment were determined by using the method suggested by Oregioni \& Aston (1984). However, concentrations of heavy metals in fish target organs were measured according to APHA (1992) to determine the correlation between different metals during different seasons. Concentrations of heavy metals in the water, sediment and fish target organs were detected after digestion for determination the bio-accumulation and bio-sedimentation factors. 


\section{Biochemical analysis:}

Biochemical parameters were determined seasonally during the study period. After dissection, a known weight of each organ was stored at $4{ }^{\circ} \mathrm{C}$ in a refrigerator for latter examinations. Total protein was determined using the Folin-Cioclten method described by Lawry et al. (1951) with its modification suggested by Ansell \& Traveuion (1967). While, total lipids were estimated according to the method of Knight et al. (1972), using a kit of Bioadwic Company. Results were converted into g/100 g wet weight. Aspartate aminotransferase (ASAT) and alanine aminotransferase (ALAT) activities in the target organs were determined according to the method suggested by Reitman \& Frankel (1957) by using a kit of Bioadwic Company. Results were converted into U/gm wet weight.

\section{Statistical analysis:}

Results were expressed in tables as mean \pm SD. ,Analysis of variance (ANOVA) was assumed according to Bailey (1981).

\section{RESULTS AND DISCUSSION}

\section{Bioaccumulation and biosedimentation factors:}

\subsection{Bioaccumulation factor (BAF):}

The present study exhibited that, the maximum value of bioaccumulation factor for cadmium was recorded during winter in the gills and kidney $(0.248$ and 0.235 , respectively) while the minimum value (0.072) occurred in the muscles during autumn. However, the highest level of bioaccumulation factor for copper was detected in the liver during spring and the lowest one was determined in the muscles during summer; being 0.378 and 0.028 , respectively. Bioaccumulation factor for iron was peaked during summer in the gills (0.376), kidney (0.591) and liver (0.797) and declined to reach its minimal value (0.130) during autumn in the muscles (Table 1).

Results indicated that bioaccumulation factor for manganese ranged between 0.008 during summer in muscles and 0.0261 during spring in liver. Higher level of bioaccumulation factor for zinc was recorded during autumn in liver and the lower one was observed during winter in muscles; being 0.411 in the former and 0.058 in the latter (Table 1).

The bioaccumulation of heavy metals in an aquatic organism depends on species, invasion pathways and chemical composition of material, metabolic characters of the sampled tissues and the surrounding environmental condition (Ozmen et al., 2008 and Younis et al., 2015). The observed high level of BAF in some fish species indicates that these fishes have a high potential to concentrate heavy metals in their organs (Eja et al., 2003). The extent of occurrence or accumulation of trace metals by organisms in different tissues is dependent on the route of entry. The accumulation process of metals toke placed by penetration the organism through gills and skin (Ayas, 2007 and Ozmen et al., 2008).

The present study was matching with Ahmed et al. (2019) who found that, the bioaccumulation factors (BAFs) of some metals were relatively lower than that obtained by Kwok et al. ( 2014) on Tilapia collected from Pearl River estuary with different rates of bioaccumulation in organisms tissues. According to the level of bioaccumulation factor, metals concentrations in organisms exceeded the concentrations of metals found in the 
surrounding environment, indicating bioaccumulation in this ecosystem (Klavinš et al., 1998 and Chiba et al., 2011).

The present results supported that fact, the deference in the levels of accumulation in different organs of fish can be attributed to the physiological role of each organ plus other factors such as regulatory ability, behavior and feeding habits may play a significant role in the deference of accumulation in these organs (Kehinde et al., 2016 and Oboh \& Okbara, 2019). Also, the chemical nature of metals, the ionic strength, and $\mathrm{pH}$ tend to be a master variable in the accumulation process (Eneji et al., 2011). Data indicated that, the general increase in mean concentration of heavy metals in the samples could be attributed to more bioaccumulation due to metal concentration arising from reduced water volume during the dry season. The fact is that, $\mathrm{Cu}$ is actively persistent in muscles due to being an essential element of living tissue (ATSDR, 2005; Zhong et al., 2018 and Traina et al., 2019).

Table 1. Bio-accumulation and bio-sedimentation factors of some heavy metals in the different organs of S. solea collected from Lake Qarun during the period from autumn, 2015 to summer, 2016.

\begin{tabular}{|c|c|c|c|c|c|c|c|c|c|}
\hline \multirow{2}{*}{ Metals } & \multirow{2}{*}{ Organs } & \multicolumn{4}{|c|}{ Bio-accumulation factor } & \multicolumn{4}{|c|}{ Bio-sedimentation factor } \\
\hline & & Gills & Kidney & Liver & Muscles & Gills & Kidney & Liver & Muscles \\
\hline \multirow{4}{*}{ Cd } & Autumn & 0.230 & 0.096 & 0.132 & $0.072 \downarrow$ & 0.185 & 0.078 & 0.107 & 0.058 \\
\hline & Winter & $0.248 \triangle$ & $0.235 \Delta$ & 0.169 & 0.156 & $0.195 \Delta$ & $0.185 \Delta$ & 0.134 & 0.123 \\
\hline & Spring & 0.183 & 0.172 & 0.206 & 0.160 & 0.155 & 0.145 & $0.174 \boldsymbol{\Delta}$ & 0.135 \\
\hline & Summer & 0.107 & 0.193 & 0.097 & 0.075 & 0.074 & 0.133 & 0.067 & $0.052 \downarrow$ \\
\hline \multirow{4}{*}{$\mathbf{C u}$} & Autumn & 0.068 & 0.082 & 0.145 & 0.052 & 0.322 & 0.399 & 0.697 & 0.248 \\
\hline & Winter & 0.109 & 0.135 & 0.247 & 0.069 & 0.566 & 0.701 & 1.284 & 0.359 \\
\hline & Spring & 0.126 & 0.159 & $0.378 \Delta$ & 0.082 & 0.526 & 0.661 & $1.577 \triangle$ & 0.340 \\
\hline & Summer & 0.078 & 0.077 & 0.192 & $0.028 \downarrow$ & $0.235 \downarrow$ & $0.232 \nabla$ & 0.575 & 0.246 \\
\hline \multirow{4}{*}{$\mathbf{F e}$} & Autumn & 0.223 & 0.340 & 0.431 & $0.130 \downarrow$ & 0.036 & 0.054 & 0.069 & $0.021 \boldsymbol{\nabla}$ \\
\hline & Winter & 0.284 & 0.387 & 0.576 & 0.207 & 0.032 & 0.043 & 0.065 & 0.023 \\
\hline & Spring & 0.204 & 0.277 & 0.284 & 0.273 & 0.058 & $0.079 \Delta$ & $\begin{array}{l}0.081 \boldsymbol{\Lambda} \\
\end{array}$ & 0.026 \\
\hline & Summer & $0.376 \triangle$ & $0.591 \Delta$ & $\begin{array}{l}0.797 \Delta \\
\end{array}$ & 0.250 & 0.031 & 0.049 & 0.066 & $0.021 \downarrow$ \\
\hline \multirow{4}{*}{ Mn } & Autumn & 0.045 & 0.0124 & 0.0144 & 0.011 & 0.029 & 0.008 & 0.009 & $0.006 \nabla$ \\
\hline & Winter & 0.084 & 0.0146 & 0.0156 & 0.010 & 0.067 & 0.011 & 0.012 & 0.007 \\
\hline & Spring & 0.115 & 0.0149 & $0.0261 \Delta$ & 0.014 & $0.068 \wedge$ & 0.009 & 0.016 & 0.008 \\
\hline & Summer & 0.045 & 0.0117 & 0.0105 & $0.008 \downarrow$ & 0.043 & 0.011 & 0.010 & 0.007 \\
\hline \multirow{4}{*}{$\mathbf{Z n}$} & Autumn & 0.261 & 0.190 & $0.411 \Delta$ & 0.114 & 1.280 & 0.932 & 2.015 & 0.560 \\
\hline & Winter & 0.193 & 0.172 & 0.343 & $0.058 \downarrow$ & 1.219 & $1.086 \Delta$ & $2.164 \Delta$ & $0.366 \downarrow$ \\
\hline & Spring & 0.250 & 0.177 & 0.299 & 0.216 & 1.100 & \begin{tabular}{l|l}
0.778 \\
\end{tabular} & 1.316 & 0.947 \\
\hline & Summer & 0.235 & 0.122 & 0.298 & 0.110 & $1.634 \wedge$ & 0.847 & 2.078 & 0.768 \\
\hline
\end{tabular}

The results exhibited the differences of some heavy metals accumulation in different tissues of fish and the gradual accumulation and increase in the liver, gills and muscles during summer and spring than other seasons. Liver of $S$. solea accumulated higher levels of $\mathrm{Cu}, \mathrm{Fe}$ and $\mathrm{Zn}$ than other organs. Similar observation was recorded by Jent $\boldsymbol{e t}$ al. (1998) and Yehia \& Sebaee (2012) who found that $\mathrm{Cd}$ and $\mathrm{Cu}$ concentration increased in fish liver. The higher accumulation in liver may alter the levels of various biochemical parameters in this organ; this may also cause severe liver damage (Ferguson, 1989). 


\subsection{Biosedimentation factor (BSAF):}

The present study exhibited that, the higher level of bio-sedimentation factor for cadmium during winter in the gills and kidney and the lower one during summer in the muscles; being 0.195 in the first organ, 0.185 in the second and 0.052 in the third (Table 1).

However, the maximum value of Bio-sedimentation factor for copper varied from 0.232 during summer in the kidney to 1.577 during spring in the liver. The minimal value of bio-sedimentation factor for iron was recorded during spring in the kidney and liver $(0.079$ and 0.081 , respectively) and the maximal value (0.021) obtained during autumn and summer in the muscles (Table 1).

The present study indicated that, bio-sedimentation factor for manganese attained its high peak during spring in the gills (0.068) and the lower one (0.006) during autumn in the muscles. Moreover, bio-sedimentation factor for zinc exhibited the increasing levels in the gills during summer (1.634) and metabolic organs (kidney and liver) during winter (1.086 and 2.164 , respectively) while, the decreasing one (0.366) was determined in the muscles during winter (Table 1).

This study showed that, bio-sedimentation levels of heavy metals in an aquatic ecosystem may be due to the increasing activity of sewage and anthropogenic pollution. This finding disagree with Leblanc \& Ceuleneer (1991) and De Mora et al. (2004) who studied the geological characters on the seabed of Oman Sea and mention that the seabed composition is mostly have more nickel sulphide content which is the natural source of nickel in the coastal areas, rather than the anthropogenic activities. Dallinger (1993) refered to that bio-sedimentation factor $(\mathrm{BSAF})>2$, the organism is macroconcentrator. If $1<\mathrm{BSAF}<2$, the organism is micro-concentrator. If $\mathrm{BSAF}<1$, the organism is de-concentrator and releasing the metal in sediment.

Heavy metal pollution at Lake Qarun is resulted from the human activities such as shipping, fishing and waste water from sewage and agriculture drainage which can increase the concentration of some metals in edible organs. Data indicated that, some organs are specified to metal than other. This result is matching with Ziyaadini et al. (2016) who concluded that, Chiton lamyi showed higher BSAF for cadmium and can be used as specifically measurement of cadmium in the aquatic environments.

Data appeared that, the higher concentration of metals in gills could be linked to their direct contact with ambient medium. This finding agree with Asante et al. (2014) who recorded that, gills are the main site of water movement and bioaccumulation center. The mean concentration of measured metals in the muscles of fishes in this study were below the allowable concentration suggested by GRWCG (2003) and WHO (2005), this result was in agreement with many authors including Choubal-Kraïem et al. (2007) and Khalil \& Faragallah (2008) who reported that, muscles is not an active organ in accumulation of most heavy metals. The differences in accumulation metal concentrations in the gills and muscles could be attributed to differences in their physiological roles. Organisms with high food intake tend to accumulate more metals concentrations, plus it has different metabolic rates and different food requirements plus their amounts (Ademoroti, 1996).

The results showed that the bioaccumulation factor of $\mathrm{Cd}, \mathrm{Fe}$ and $\mathrm{Mn}$ in fish were greater than biosedimentation factor and this implies that fish bioaccumulated these metals 
from water; this finding is matching with Barron (1995). While, $\mathrm{Cu}$ and $\mathrm{Zn}$ accumulation in fishes from water were lower than that from sediment and this implies that fish bioaccumulated these metals from sediment. This result agrees with Abdel-Baki et al. (2011) and Asante et al. (2014) who concluded this finding to feeding behavior of the studied fish.

The increasing of bioaccumulation and biosedimentation factors in the organs reflects the warning signal for fish health and human consumption. The present study shows that precaution measures need to be taken in order to prevent future heavy metal pollution. Therefore, further monitoring programs should be conducted.

\section{Biochemical studies:}

\subsection{Metabolic parameters:}

\subsubsection{Total proteins:}

Results in Table (2) declared that, total proteins in the kidney of $S$. solea, was ranged between $3.26 \pm 0.41 \mathrm{~g} / 100 \mathrm{~g}$ wet wt. during autumn and 5.77 $\pm 1.48 \mathrm{~g} / 100 \mathrm{~g}$ wet wt. during winter. Also, the maximum average value of total proteins in the liver was detected during winter and the minimum average value was determined during autumn; being $6.83 \pm 0.56$ $\mathrm{g} / 100 \mathrm{~g}$ wet wt. and $4.03 \pm 0.72 \mathrm{~g} / 100 \mathrm{~g}$ wet wt., respectively. In the muscles, however, total proteins was peaked during spring and declined during summer $(4.78 \pm 0.47$ and $3.25 \pm 0.53$ $\mathrm{g} / 100 \mathrm{~g}$ wet wt., respectively).

The present study indicated that, total proteins in the target organs were exhibited the higher peak during winter may be attributed to the combined effects of high food availability to storing material prior to spawning. These findings are in agreement with Tulgar \& Berik (2012); Sabae \& Mohamed (2015); Ragab (2017); Ghanem (2019) and Mohamed (2019).

Data explained that, the depletion of proteins content in the target organs reflected to the changes in water characters by the stress of pollutants, dissolved in agriculture drainage waters that may critically influence the growth rate and quality of the fishes which feed on bottom founa induced by bioaccumulation of metals. From another angle of view, the lower value of total proteins in the fish organs of Lake Qarun may be due to the higher level of salinity in this lake, which are unfavorable for them, or may be due to the lower density of zooplankton and nutrients (James et al., 1991). Furthermore, Vutukuru (2005) reported that, depletion in protein content at the target organs may be attributed to that, it was taken as an alternative source of energy demand that induced by different pollutants in lake Qarun.

\subsubsection{Total lipids:}

The present study declared that, total lipids in the kidney of $S$. solea, was fluctuated between $1.25 \pm 0.12 \mathrm{~g} / 100 \mathrm{~g}$ wet wt. during summer and $1.78 \pm 0.19 \mathrm{~g} / 100 \mathrm{~g}$ wet wt. during spring. Furthermore, the maximum average value of total lipids in the liver was detected during autumn and the minimum one was determined during summer; being $1.63 \pm 0.27 \mathrm{~g} / 100$ $\mathrm{g}$ wet wt. in the former and $1.09 \pm 0.13 \mathrm{~g} / 100 \mathrm{~g}$ wet wt., in the latter. Moreover, total lipids in the muscles showed the increasing levels during autumn and spring $(1.30 \pm 0.15 \mathrm{~g} / 100 \mathrm{~g}$ wet wt. and $1.23 \pm 0.10 \mathrm{~g} / 100 \mathrm{~g}$ wet wt. respectively). While, the lowest average values were detected during winter and summer; being $1.13 \pm 0.12 \mathrm{~g} / 100 \mathrm{~g}$ wet wt. in the former and $1.11 \pm 0.06 \mathrm{~g} / 100 \mathrm{~g}$ wet wt. in the latter (Table 2).

The present study indicated that, total lipids in the target organs were exhibited the higher peak during cold or semi-cold seasons may be attributed to the combined effects of 
nutrients availability to storing material. These findings are in agreement with Tulgar \& Berik (2012) and Ragab (2017). Depletion in lipids contents in the metabolic organs (kidney and liver) may be due to the action of toxicity which suppresses the activity of enzymes responsible for lipid transformation ultimately causing disturbance in lipid metabolism and lead to the decreasing in cholesterol level. Similar findings were found by Shakoori $\boldsymbol{e t}$. al. (1996); Virk \& Sharma (1999) and Mohamed (2019) and differ with Sancho et al. (1998); Chandra \& Khuda-Bukhsh (2004) and Blaner et al. (2005).

The decreasing level of total lipids in the muscles of studied fish collected from Lake Qarun may be attributed to many reasons; (1) the secretion of catecholamine and corticosteroids in the blood stream after the toxicant stress that produces an enhanced in metabolic rate which in turn reduces the metabolic reserves, (2) the use of energy-rich lipids for energy production during toxic stress. This may be attributed to the changes in water quality by the action of heavy metals that may critically affects directly on the growth and goodness of fishes (Khalil \& Hussein, 1996 and Ghanem et al., 2015). Moreover, the agricultural drainage waters is generally rich with nitrogen, phosphorous and organic matter that causes appropriate changes in the physical and chemical features of water. This may affect indirectly on fish growth and productivity of fishes through their effects upon bacterial flora, phytoplankton and zooplankton (Shaaban et al., 1999 and Fayed et al., 2001). Some metals are with very strong binding (permanent store) and that strong bound metals in fish flesh are not easily influenced by the environmental change, the elimination of metals is an active biochemical and physiological processes (Barak \& Mason, 1990).

Table 2. Seasonal variations of biochemical parameters (Mean \pm S.D.) in the target organs of $S$. solea collected from Lake Qarun, during the period from autumn, 2015 to summer, 2016.

\begin{tabular}{|c|c|c|c|c|c|c|}
\hline Parameters & Seasons & Autumn & Winter & Spring & Summer & $\begin{array}{l}\text { Annual } \\
\text { Average }\end{array}$ \\
\hline \multirow{3}{*}{$\begin{array}{l}\text { Total proteins } \\
\text { (g/100 g wet wt) }\end{array}$} & Kidney & $3.26 \pm 0.41$ & $5.77 \pm 1.48$ & $4.17 \pm 0.58$ & $4.08 \pm 0.64$ & $4.32 \pm 1.05$ \\
\hline & Liver & $4.03 \pm 0.72$ & $6.83 \pm 0.56$ & $4.79 \pm 0.70$ & $6.01 \pm 0.58$ & $5.42 \pm 1.25$ \\
\hline & Muscles & $4.14 \pm 0.43$ & $4.42 \pm 1.00$ & $4.78 \pm 0.47$ & $3.25 \pm 0.53$ & $4.15 \pm 0.65$ \\
\hline \multirow{3}{*}{$\begin{array}{c}\text { Total lipids } \\
\text { (g/100 g wet wt) }\end{array}$} & Kidney & $1.43 \pm 0.08$ & $1.75 \pm 0.07$ & $1.78 \pm 0.19$ & $1.25 \pm 0.12$ & $1.55 \pm 0.26$ \\
\hline & Liver & $1.63 \pm 0.27$ & $1.16 \pm 0.24$ & $1.45 \pm 0.22$ & $1.09 \pm 0.13$ & $1.33 \pm 0.25$ \\
\hline & Muscles & $1.30 \pm 0.15$ & $1.13 \pm 0.12$ & $1.23 \pm 0.10$ & $1.11 \pm 0.06$ & $1.19 \pm 0.09$ \\
\hline \multirow{3}{*}{$\begin{array}{c}\text { ASAT } \\
(\text { U / g wet wt })\end{array}$} & Kidney & $223.33 \pm 17.06$ & $233.33 \pm 13.53$ & $256.67 \pm 12.49$ & $343.33 \pm 10.54$ & $264.17 \pm 54.59$ \\
\hline & Liver & $223.33 \pm 15.10$ & $243.33 \pm 14.80$ & $273.33 \pm 13.53$ & $236.67 \pm 11.36$ & $244.17 \pm 21.15$ \\
\hline & Muscles & $323.33 \pm 13.53$ & $313.33 \pm 27.22$ & $326.67 \pm 22.72$ & $233.33 \pm 20.42$ & $299.17 \pm 44.25$ \\
\hline \multirow{3}{*}{$\begin{array}{c}\text { ALAT } \\
\text { (U / g wet wt) }\end{array}$} & Kidney & $256.67 \pm 2.31$ & $106.67 \pm 4.62$ & $220.00 \pm 28.00$ & $276.67 \pm 18.90$ & $215.00 \pm 75.94$ \\
\hline & Liver & $356.67 \pm 9.24$ & $163.33 \pm 34.02$ & $256.67 \pm 24.44$ & $363.33 \pm 16.17$ & $285.00 \pm 94.65$ \\
\hline & Muscles & $113.33 \pm 23.44$ & $106.67 \pm 2.31$ & $306.67 \pm 41.63$ & $226.67 \pm 18.90$ & $188.34 \pm 96.21$ \\
\hline
\end{tabular}

\subsection{Enzymatic activities:}

\subsubsection{Aspartate aminotransferase (ASAT):}

Results in Table (2) revealed that, aspartate aminotransferase activity (ASAT) in the kidney of $S$. solea, was fluctuated between $223.33 \pm 17.06 \mathrm{U} / \mathrm{g}$ wet wt. during autumn and $343.33 \pm 10.54 \mathrm{U} / \mathrm{g}$ wet wt. during summer. During other seasons, it was nearly similar; being $233.33 \pm 13.53 \mathrm{U} / \mathrm{g}$ wet wt. during winter and $256.67 \pm 12.49 \mathrm{U} / \mathrm{g}$ wet wt. during spring. On the other hand, the highest activity of ASAT in the liver was determined during spring and the lowest one was detected during autumn; being $273.33 \pm 13.53$ and $223.33 \pm 15.10 \mathrm{U} / \mathrm{g}$ wet wt., respectively. During the remaining seasons, it was nearly similar. In the muscles, however, it 
showed a higher level $(326.67 \pm 22.72 \mathrm{U} / \mathrm{g}$ wet wt.) during spring and the lower one (233.33 $\pm 20.42 \mathrm{U} / \mathrm{g}$ wet wt.) during summer.

\subsubsection{Alanine aminotransferase (ALAT):}

The present study revealed that, alanine aminotransferase activity (ALAT) in the kidney of $S$. solea, was varied from $106.67 \pm 4.62 \mathrm{U} / \mathrm{g}$ wet wt. during winter to $276.67 \pm 18.90$ $\mathrm{U} / \mathrm{g}$ wet wt. during summer. During other seasons, it was higher during autumn than spring; being $256.67 \pm 2.31$ and $220.00 \pm 28.00 \mathrm{U} / \mathrm{g}$ wet wt, respectively. In the liver of sole fish, it showed the highest peak during summer and the lowest one during winter; being $363.33 \pm 16.17 \mathrm{U} / \mathrm{g}$ wet wt. in the former and $163.33 \pm 34.02 \mathrm{U} / \mathrm{g}$ wet wt. in the latter. A high peak of ALAT in the muscles was recorded during spring and the lower one during winter;

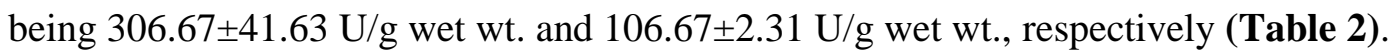

The present study supported this fact, aspartate and alanine aminotransferase are liver specific enzymes and they are sensitive markers of hepatotoxicity and histopathologic changes and can be assessed within a shorter time. The higher accumulation in liver may alter the levels of various biochemical parameters in liver. This may also cause severe liver damage (Ferguson, 1989). Results supported this fact; the elevation of ASAT and ALAT activities in the target organs might reflect the early toxic effects of heavy metals on the hepatic enzyme activities which lead to the tissue damage and liver necrosis. These results are matching with Zaghloul et al. (2011); Ghanem (2014); Ali et al. (2016) and Mohamed (2019) and differ with Gill et al. (1991) whom found that, the reduction of aminotransferases levels in various organs may be resulted from the reduction of enzymes secretion permeability of cell membrane. Biochemical profile in fish has proved to be a sensitive index for evaluation of the fish metabolism under metallic stress. Almeida et al. (2001) proved that, fish subjected to metals showed reduced levels of proteins, ASAT and ALAT activities in the fish muscles. Also, Luskova et al. (2002) and Ali et al. (2016) reported the changes in biochemical profile are mirror changes in metabolism and biochemical processes of the organism, resulting from the effect of pollutants such as the heavy metals.

\section{Statistical analysis:}

Analysis of variance (Table 3) indicated that, there are significant differences $(p<0.05)$ at one way of total proteins except between the different organs showed non-significant. Moreover, one way of analysis for data at total lipids exhibited a significant difference $(\mathrm{p}<0.05)$. ASAT activity recorded non-significance at all sources of variance except the different organs at one way, it showed a significant difference. Furthermore, a highly significant difference $(\mathrm{p}<0.01)$ at one way of analysis for activity of alanine enzyme. From another angel, two way of ANOVA indicated non-significance for all parameters.

Table 3. Analysis of variance (ANOVA) on biochemical parameters in the sole fish, $S$. solea, collected from Lake Qarun. (Data represented by F-value)

\begin{tabular}{||c|c|c|c|c||}
\hline Source of variances & Total proteins & Total lipids & ASAT & \multirow{2}{*}{ ALAT } \\
\hline Seasons & $3.310^{*}$ & $4.716^{* *}$ & 1.189 n.s. & $6.061^{* * *}$ \\
\hline Organs & 1.342 n.s. & $2.745^{*}$ & $4.383^{* *}$ & $4.691^{* *}$ \\
\hline Seasons*organs & 0.235 n.s. & 0.470 n.s. & 0.890 n.s. & 2.115 n.s. \\
\hline
\end{tabular}

Note: $*=$ Significant at $\mathrm{p}<0.05$. $* *=$ Significant at $\mathrm{p}<0.01$. n.s. $=$ non-significant. 


\section{CONCLUSION}

Levels of heavy metals found in the muscles were within the safe limits for human health. The increasing of bioaccumulation and biosedimentation factors in edible organs may be considered as an important signal for negatively health of fish and human consumption. In addition, it is necessary to exercise more cautions towards water resources in these areas to keep water suitability for aquaculture to prevent future heavy metal pollution which leading to production of good fish, with negatively affects the human health. Therefore, further monitoring programs should be conducted.

\section{REFERENCES}

Abdel-Baki, A. S.; Dkhil, M. A. and Al-Quraishy, S. (2011). Bioaccumulation of some heavy metals in tilapia fish relevant to their concentration in water and sediment of Wadi Hanifah, Saudi Arabia. African Journal of Biotechnology.,10(13):2541-2547.

Ademoroti, C. M. A. (1996). Environmental Chemistry and Toxicology mFoludex. Press, Ibadan, 215pp.

Adhikari, S.; Sarkar, B.; Chatterjee, A.; Mahapatra, C. and Ayyappan, S. (2004). Effects of cypermethrin on certain hematological parameters and prediction of their recovery in a freshwater teleost, Labeo rohita (Hamilton). Ecotoxicology and Environmental Safety, 58(2): 220-226.

Ahmed, Sh. A.; Sultana, Sh.; Habib, A.; Ullah, H.; Musa, N.; Hossain, M. B.; Rahman, Md. M. and Sarker, Md. S. I. (2019). Bioaccumulation of heavy metals in some commercially important fishes from a tropical river estuary suggests higher potential health risk in children than adults. Plos one., 14(10): 1-21.

Ali, M. and Fishar, M. (2005). Accumulation of trace metals in some benthic invertebrate, fish species relevant to their concentration in water and sediment of Lake Qarun, Egypt. Egyptian Journal of Aquatic Research, 31: 289-301.

Ali, N. A.; Mohamed, M. A. and Abd El-Hameed, E. A. A. (2016). Water quality and heavy metals monitoring in water and tissues of Nile tilapia fish from different governorates "Egyptian Aquaculture farms" Egypt. J. Aquat. Biol. \& Fish., 20(3): 103-113.

Almeida, J. A; Diniz, Y. S; Marques, S. F. G.; Faine, I. A.; Ribas, B. O. and Burneiko, R. C. (2002). The use of oxidative stress responses as biomarkers in Nile Tilapia (Oreochromis niloticus) exposed to in vivo cadmium contamination. Environ Int., 27:673-679.

Almeida, J. E.; Novelli, M.; Dal, P. S. and Junior, R. (2001). Environmental cadmium exposure and metabolic responses of the Nile tilapia; Oreochromis niloticus. Environ. Pollut., 114:169-175.

Ansell, A. D. and Trevallion, A. (1967). Studies on Tellina tenuis da Costal. Seasonal growth and biochemical cycle. J, exp. Mar. Biol. Ecol., (1):220-235.

APHA (American Public Health Association), (1992). Standard methods of the examination of water and waste water. $17^{\text {th }}$ eds, Washington D.C. 1015 pp.

Asante, F.; Agbeko, E.; Addae, G. and Quainoo, A. K. (2014). Bioaccumulation of heavy metals in water, sediments and tissues of some selected fishes from the Red Volta, Nangodi in the Upper East Region of Ghana, British Journal of Applied Science \& Technology., 4(4): 594-603. 
ATSDR (Agency for Toxic Substances and Disease Registry), (2005). Toxicological Profile for Zinc. U.S. Department of Health and Human Services, Public Health Service, Atlanta.

Ayas, Z. (2007). Trace Element Residues in Eggshells of Grey Heron (Ardea cinerea) and BlackCrowned Night Heron (Nycticorax nycticorax) from Nallihan Bird Paradise, Ankara-Turkey. Ecotoxicology, 16, 347-352.

Ayas, Z., Ekmekci, G., Ozmen, M. and Yerli, S.V. (2007). Histopathological Changes in the Livers and Kidneys of Fish in Sariyar Reservoir, Turkey. Environmental Toxicology and Pharmacology, 23, 242-249.

Bailey, N. T. J. (1981). Statistical methods in biology. 2nd Ed. (Biological Science Texts): $216 \mathrm{pp}$.

Bakry, F. A.; Atwa, M. T. and Attia, M. M. (2018). Three Strigeid cercariae from Littorina littorea snail, Qarun Lake, Fayoum, Egypt, Veterinary World, 11(3): 310-315.

Barak, N. A. E. and Mason, C. F. (1990). Mercury, cadmium, and lead in eels and roach. The effects of size, season and locality on metal concentrations in flesh and liver. Science of the Total Environment, 92: 249 - 256.

Barhoumi, S.; Messaoudi, I.; Gagne, F. and Kerkeni A. (2012). Spatial and seasonal variability of some biomarkers in Salaria basilisca (Pisces: Blennidae): Implication for biomonitoring in Tunisian coasts, Ecological Indicators, 14 (1): 222-228.

Barron, M. G. (1995). Bioaccumulation and concentration in aquatic organisms. In: Hoffman D.J., Rattner, B.A., Burton, Jr., G.A., Cairns, J. (Eds.), Handbook of Ecotoxicology.Lewis Publishers, Boca Raton, FL.;652-666.

Benli, A. C. (2005). Investigation of acute toxicity of cyfluthrin on tilapia fry, Oreochromis niloticus. Environ. Toxicol. and Pharmacol. In press, corrected proof, available on line.

Blaner, C.; Curitis, M. and Chan, H. (2005). Growth, nutritional composition, hematology of Artic chair (Salvelinus alpinus) exposed to toxaphene and tapeworm (Diphyllobothrium dendritiam), Archive of Environmental Contamination and Toxicology., 48: 397-404.

Bowen, H. J. M. (1966). Trace elements in biochem. Academic. Press, New York., 241p.

Chandra, P. and Khuda-Bukhsh, A. R. (2004). Genotoxic effects of cadmium chloride, azadirachtin treated singly and in combination in fish. Ecotoxicol. Environ. Saf. 58 (2): 194201.

Chavan, V. R. and Muley, D.V. (2014). Effect of heavy metals on liver and gill of fish Cirrhinus mrigala. Int .J. Curr. Microbiol. Appl. Sci., 3(5): 277-288.

Chiba, W. A.C.; Passerini, M. D. and Tundisi, J. G.(2011). Metal contamination in benthic macroinvertebrates in a sub-basin in the southeast of Brazil. Braz. J. Biol., 71( 2): 391-399.

Choubal-Kraïem, M.; Njimi, W.; Tissaoui, C. H.; Thompson, J. R. and Flower, R. J. (2007). Seasonal variations of heavy metals $(\mathrm{Cd}, \mathrm{Pb}$, and $\mathrm{Hg})$ in sediments and in mullet, Mugil cephalus (Mugilidae) from the Ghar El Mehl Lagoon (Tunisia)., Transitional Waters Bulletin., 4:45-52.

Cogun, H. Y. and Kargin, F. (2004). Effects of $\mathrm{pH}$ on the mortality and accumulation of copper in tissues of Oreochromis niloticus. Chemosphere., 55(2): 277-282.

Dallinger, R. (1993). Strategies of metal detoxification in terrestrial invertebrates. In: Ecotoxicology of metals in invertebrates. (R.P. Eds: Dallinger R, Ed.) Boca Raton: Lewis Publisher. 246-332. 
De Mora, S.; Fowler, S.W.; Wyse, E. and Azemard, S. (2004). Distribution of heavy metals in marine bivalves, fish and coastal sediments in the Gulf and Gulf of Oman. Marine Pollution Bulletin, 49: 410-424.

Delaney, M. A. and Klesius, P. H. (2004). Hypoxic conditions induce Hsp70 production in blood, brain , head kidney of juvenile Nile tilapia, Oreochromis niloticus. Aquaculture., 236(1-4): 633-644.

Eaton, A. and Franson, M. (2005). Standard Methods for the Examination of Water \& Wastewater, 21 st. ed., Centennial ed.; American Publisher Health Association: DC: 188189.

Eja, M.E.; Ogri, O.R. and Arikpo, G.E. (2003). Bioconcentration of heavy metals in surface sediments from the Great Kwa Rivers Estuary, Calabar, South Eastern Nigeria. Journal of Nigerian Environmental Society, 2: 247-256.

El-Shabrawy, G. M. and Taha, O. E. (1999). Effect of grazing pres- sure on phytoplankton assemblage in Lake Qarun, ElFayoum Egypt. Egypt. J. Aquat. Biol. \& Fish., 3 (3): 81-92.

Eneji IS, Sh.; Ato, R. and Annune, P. A. (2011). Bioaccumulation of heavy metals in fish (Tilapia zillii and Clarias gariepinus) organs from River Benue, North-Central Nigeria. Pak J Anal Environ. Chem., 12(1-2): 25-31.

Fayed, H. M.; Zaghloul, K. H.; Abdel-Monem, S. and Mohamed, H. A. (2001). Biological responses of the Nile Tilapia, Oreochromis niloticus, and the Nile catfish, Clarias gariepinus, induced by agricultural and industrial pollutants. J. Union Arab Biol., 16(A): 543-568.

Ferguson, H. W. (1989). Systematic pathology of fish. Ames. IA: Iowa State University, Press.

Ghanem, M. H. M. (2011). Seasonal variations of total proteins, lipids and carbohydrates in cultivated, brackish and salt water fishes with special references to their nutrient values. Ph.D. Thesis, Zool. Dept. Fac. Sci., Al-Azhar Univeristy, Cairo, 396pp.

Ghanem, M. H. M. (2014). Effect of heavy metals on some physiological responces in two fish species inhabiting Mediterranean Sea coast; Damietta Governorate, Egypt. Al-Azhar Bulletin of Science., 25: (1): 43-56.

Ghanem, M. H. (2019). Physiological Responses Influenced by Certain Heavy Metals at the Mullet Fish, Mugil cephalus Inhabiting Mediterranean Sea Coast at Damietta Governorate, Egypt. Egypt. Acad. J. Biolog. Sci., 11(3C): 97- 108.

Ghanem, M. H.; Shehata, S. M.; Abu-Zaid, M. M.; Abdel-Halim, A. M. and Abbas, M. M. (2015). Accumulation of some heavy metals in the muscles of Diplodus sargus, inhabiting El-Mex Bay (Alexandria, Mediterranean Sea) with special references to its physiological responses. International J. OF Environ. Sci. and Engin., 6: 1- 13.

Gill, T. S.; Pande, J. and Tewari, H. (1991). Individual and combined toxicity of common pesticide to teleost Puntius conchonitus. Indial Journal of experiment and Biology., 29:145148.

GRWCG (Ghana Raw Water Criteria and Guidelines) (2003). Aquaculture water use. CSIRWater Research Institute., Volume 5.

James, R.; Sampath, K.; Sivakiiman, V. and Manthiramoorthy, S. (1991). Individual and combined effects of heavy metals on survival and biochemistry of Oreochromis mossambicus. Indian J. Fish ., 38 (1):49-54. 
Jent, S.; Heing, J. S. and Ttate, C.M. (1998). Concentration distribution and composition of selected trace metals in bed sediment and fish tissue in the South Platte River Basin, USA, 1992-1993. National Water Quality Assessment (NAWQA) program report.

Kehinde, O. H.; Ajibola, I. O.; Isaac, S. and Segun. O. O. (2016). Determination of heavy metal genotoxicity and their accumulation pattern in different fish organs of selected fish species collected from the Asa River, Ilorin, Kwara State, Nigeria. J. Appl. Sci. Environ. Manage., 20(3): 735-745.

Khalil, M. and Faragallah, H. (2008). The distribution of some leachable and total heavy metals in core sediments of Manzala Lagoon, Egypt. Egypt. J. Aquat. Res., 34(1): 1-11.34.

Khalil, M. T. and Hussein, A. H. (1996). Recycling and reuse of wastewater for fish farming: An experimental field study at Sewage Treatment Plant, Egypt. J. Egypt.Ger. Soc. Zool., 19(B): 59-79.

Klavinš, M.; Briede, A.; Parele, A.; Rodinov, V. and Klavina, I. (1998). Metal accumulation in sediments and benthic invertebrates in lakes of Latvia. Chemosphere., 36(15): 3043-3053.

Knight, J. A.; Anderson, S. and Rawie, J. M. (1972). Chemical basic of the sulfophosphovanillin reaction for estimating total serum lipid. Clin. Chem., 18: 199-202.

Kwok, C.; Liang, Y.; Wang, H.; Dong, Y.; Leung, S. and Wong, Mh. (2014). Bioaccumulation of heavy metals in fish and Ardeid at Pearl River Estuary, China. Ecotoxicology and Environmental Safety. 106:62-67.

Lawry, O. H.; Rosebrough, N. J.; For, A. L. and Randal, R. J. (1951). Protein measurement with the folin phenol reagent. J. Biol. Chem. (193):265-275.

Leblanc, M. and Ceuleneer, G., (1991). Chromite crystallization in a multicellular magma flow: Evidence from a chromatite dike in the Oman Ophiolite. Lithosphere, 27, 231-257.

Luskova, V.; Svodoba, M. and Koláŕová, J. (2002). Acta Vet. Brno, 71: 117 - 123.

Mansour, S. A. and Sidky, M. M. (2003). Ecotoxicological studies. 6. The first comparative study between Lake Qarun and Wadi El-Rayan wetland (Egypt), with respect to contamination of their major components.

Mansour, S. A; Messeha, S. S. and Sidky, M. M. (2000). Eco-toxicological Studies. 1. Qualitative and quantitative determination of salt composition in Lake Qarun water and its sources. Egypt. J. Aquat. Biol. Fish. 4(3): 271-303.

Mohamed, A. Y. (2019). Effect of certain environmental pollutants on different fish species inhabiting Lake Qarun, Egypt. M.Sc. Thesis, Fac. of Agric, Al-Azhar Univ., Cairo.274pp

Mohamed, F. A. S. (2009). Histopathological studies on Tilapia zillii and Solea vulgaris from Lake Qarun, Egypt. World Journal of Fish and Marine Sciences 1(1): 29-39.

Mohamed, F. A. S. and. Gad, N.S. (2008). Environmental Pollution - Induced biochemical changes in tissues of T. zilli, S. vulagris and M. capito from Lake Qarun, Egypt. Global Veterinaria., 2(6): 327 - 336.

Nelson D. L. and Cox M. M. (2000). Lehninger principles of biochemistry, New York. Worth Publishers, pp. 623- 58.

Oboh, I. P. and Okpara, B. C. (2019). Bioaccumulation of heavy metals and assessment of the human health risk of consumption of Clarias gariepinus and Parachanna obscura from the Owan River, Edo State, Nigeria., BIOLOGIJA. 65(3): 192-201. 
Oregioni, B. and Aston, S. (1984). The determination of selected trace metals in marine sediments by flame atomic absorption spectrophotometry. IAEA, Monaco laboratory, Internal Report.

Ozmen, M.; Ayas, Z.; Gungordu, A.; Ekmekci, GF. and Yerli, S. (2008). Ecotoxicological assessment of water pollution in Sariyar Dam Lake, Turkey., Ecotoxicology and Environmental Safety., 70:163-173.

Ragab, A. M. M. (2017). Biological Studies On Some Bony Fishes With Special Reference To Their Feeding Habits And Nutritional Values. M.Sc. Thesis, Zool. Dept, Fac. Sci., Al-Azhar Univ., Egypt., 10-24 pp.

Reitman, S. and Frankel, S. A. (1957). A colorimetric method for the determination of serum glutamic oxaloacetic and glutamic pyruvic transaminases. Am J Clin Pathol 28:56-63.

Sabae, S. Z. and Ali, M. H. (2004). Distribution of nitrogen cycle bacteria in relation to physicochemical conditions of a closed saline lake (Lake Qarun, Egypt). J. Egypt. Acad. Soc. Environ. Develop., 5(1): 145-167.

Sabae, S. Z. and Mohamed, F. A. (2015). Effect of Environmental Pollution on the Health of Tilapia spp. from Lake Qarun. J. Global Veterinaria Develop., 14 (3): 304-328.

Saeed, S. M. and Shaker, I. M. (2008). Assessment of heavy metals pollution in water and sediments and their effect on Oreochromis niloticus in the northern delta lakes, Egypt. 8th International Symposium on Tilapia in Aquaculture 2008.

Sancho, E.; Ferrando, M.D.; Fernandez, C. and Andreu, E. (1998). Liver energy metabolism of Anguilla anguilla, after exposure to fenitrothion. Ecotoxicol. Environ. Saf., 41(2): 168175.

Shaaban, M. T.; Khallaf, E. A.; Nagdy, Z. A. and El-Gammal, M. A. (1999). Variation of biological dynamics and physicochemical fluctuations, in water of fish ponds due to different (organic and inorganic) fertilizers applications. Union Arab Biologists, 8(B): 293-313.

Shakoori, A. R.; Mughal, A. L. and Iqbal, M. J. (1996). Effects of sublethal doses of fenvalerate (A. synthetic pyrethroid, Aadministered continuously for four weeks) on the blood, liver and muscle of a freshwater fish Ctenopharyngodon idella. Bulletin of Environmental Contamination Toxicology. (57):487-494.

Traina, A.; Bono, G., Bonsignore, M.; Falco, F., Giuga, M.and Quinci, EM. (2019). Heavy metals concentrations in some commercially key species from Sicilian coasts (Mediterranean Sea): Potential human health risk estimation. Ecotoxicology and Environmental Safety., 168:466-478.

Tulgar, A. and Berik, N. (2012). Effect of Seasonal Changes on Proximate Composition of Red Mullet (Mullus barbatus) and Hake (Merluccius merluccius) were catched from Saroz Bay. Res. J. of Biol., 02 (2): 45-50.

Virk S. and Sharma R. C. (1999). Biochemical changes induced by Nickel and Chromium in the liver of Cyprinus carpio (L). Pollution Research, 18(3): 217-222.

Vutukuru, S., (2005). Acute effects of hexavalent chromium on survival, oxygen consumption, hematological parameters and some biochemical profiles of the Indian major carp, Labeo rohita. Int. J. Environ. Res. Pubic Health, 2: 456-462.

WHO (2005). Guidelines for drinking water. WHO, Geneva.

Yehia, H. M. and Sebaee, E. Sh. (2012). Bioaccumulation of heavy metals in water, sediment and fish (Oreochromis niloticus and Clarias anguillaris), in Rosetta branch of the River Nile, Egypt. African Journal of Biotechnology., 11(77): 14204-14216. 
Younis, A. M.; Amin, H. F.; Alkaladi, A. Y. and Mosleh, Y. I. (2015). Bioaccumulation of Heavy Metals in Fish, Squids and Crustaceans from the Red Sea, Jeddah Coast, Saudi Arabia. Open Journal of Marine Science., 5: 369-378.

Zaghloul, K. H.; Omar, W. A.; Abdel-Khalek, A. A and Abo-Hegab, S. (2011). Ecological monitoring of Mediterranean Solea aegyptiaca trans- planted into Lake Qaroun, Egypt. Aust J Basic Appl Sci., 5:851-862.

Zhong, W.; Zhang, Y.; Wu, Z.; Yang, R.; Chen, X. and Yang, J. (2018). Health risk assessment of heavy metals in freshwater fish in the central and eastern North China. Ecotoxicology and Environmental Safety. 157:343-349.

Ziyaadini, M.; Yousefiyanpour, Z.; Ghasemzadeh, J. and Zahedi, M.M. (2016). Biotasediment accumulation factor and concentration of heavy metals $(\mathrm{Hg}, \mathrm{Cd}, \mathrm{As}, \mathrm{Ni}, \mathrm{Pb}$ and $\mathrm{Cu}$ ) in sediments and tissues of Chiton lamyi (Mollusca: Polyplacophora: Chitonidae) in Chabahar Bay, Iran. Iranian Journal of Fisheries Sciences., 16(4) 1123-1134.

\section{ARABIC SUMMARY}

$$
\begin{aligned}
& \text { تأثير التراكم والترسيب الحيوى لبعض العناصر الثقيلة على بعض الإستجابات البيوكيميائية فى سمكة موسى } \\
& \text { القاطنة فى بحيرة قارون، مصر. } \\
& \text { أحمد ياسين هاشم محمد الوصيفي1، محمد حامد محمد غانم²، محمود محمد محمد البمبي ، ، فؤاد أحمد فهمي علي } 3
\end{aligned}
$$

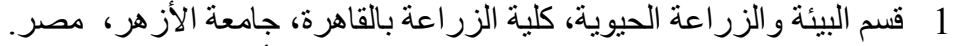

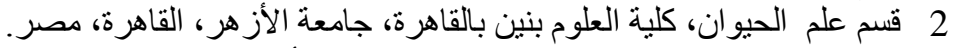

$$
\begin{aligned}
& 3 \text { ق قسم وقاية النبات، كلية الزر اعة بالقاهرة، جامعة الاز هر، القاهرة، مصر. }
\end{aligned}
$$

تم اجر اء هذه الدراسة خلال الفترة من أكتوبر، 2015 إلى سبتمبر، 2016م، لرصد وتقبيم معاملى التراكم و الترسيب

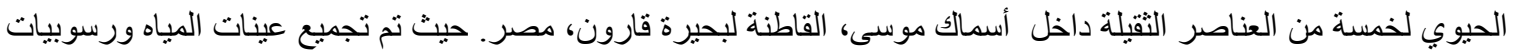

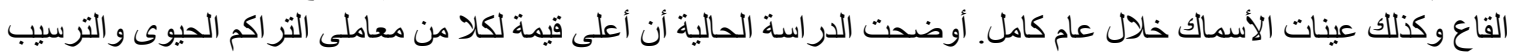

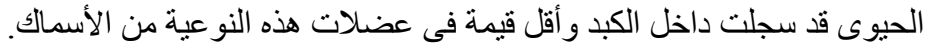

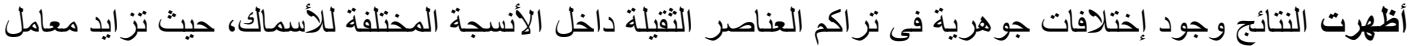

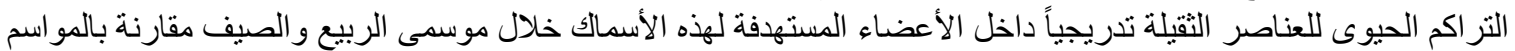

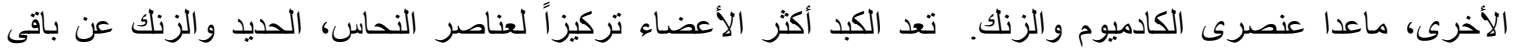

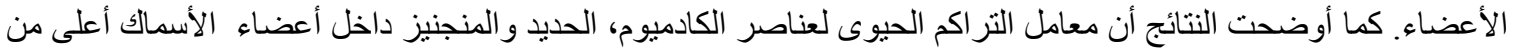

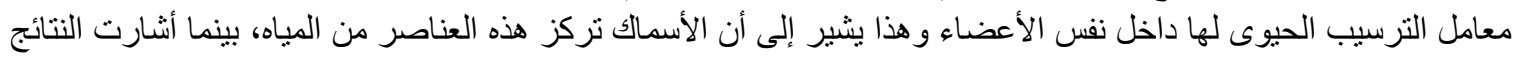

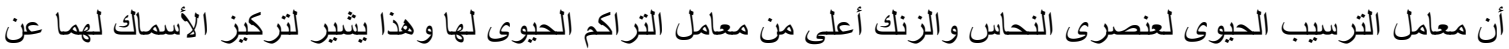
طريق رسوبيات القاع.

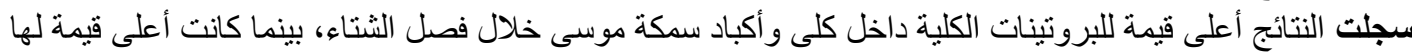

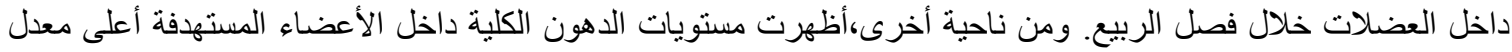

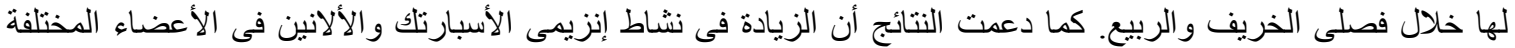

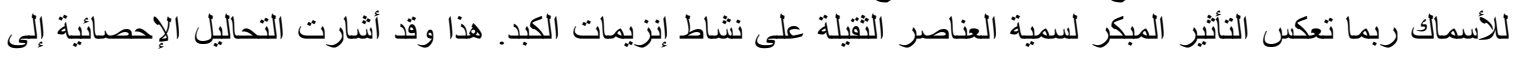

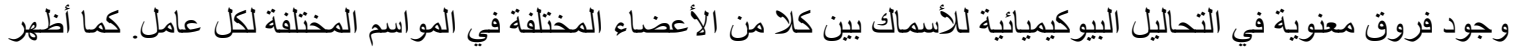
عدم وجود فروق معنوية فى حالة التداخل بين قيم المو اسم المختلفة و الأعضاء المختاء لاعلفة. 